\title{
Effect of 1-year treatment with interferon- $\beta 1 b$ on thyroid function and autoimmunity in patients with multiple sclerosis
}

\author{
F Monzani, N Caraccio, G Meucci ${ }^{1}$, F Lombardo ${ }^{1}$, G Moscato ${ }^{1}$, A Casolaro, M Ferdeghini ${ }^{2}$, \\ L Murri ${ }^{1}$ and E Ferrannini \\ Departments of Internal Medicine, ${ }^{1}$ Neurosciences and ${ }^{2}$ Oncology, University of Pisa School of Medicine, Pisa, Italy \\ (Correspondence should be addressed to F Monzani, Department of Internal Medicine, University of Pisa, via Roma 67, I-56126 Pisa, Italy)
}

\begin{abstract}
Objective: Interferon- $\beta$ (IFN- $\beta$ ) is a widely used therapy for multiple sclerosis (MS), a demyelinating disease of the central nervous system. This study has evaluated the effect on thyroid function and autoimmunity of a 1-year treatment with IFN- $\beta 1 \mathrm{~b}$ in patients with MS.

Patients: We studied 31 patients (age $34 \pm 7$ years, 21 women) with relapsing-remitting MS during IFN- $\beta 1 \mathrm{~b}$ treatment of 1 year duration. Systematic thyroid assessment and measurements of serum interleukin-6 (IL-6) levels were performed at baseline and every 3 months during treatment.

Results: Sixteen percent of the patients had autoimmune thyroiditis before IFN- $\beta 1 \mathrm{~b}$, all positive for anti-peroxidase antibodies. The overall incidence of thyroid dysfunction was 33\% over 1 year $(10 \%$ hyperthyroidism, $23 \%$ hypothyroidism). Thyroid autoimmunity developed in 5/26 patients (19\%), in one case without dysfunction. In addition to autoantibody positivity at baseline, female gender and the presence of an ultrasound thyroid pattern suggestive of thyroiditis were identified by multiple logistic regression as additional risk predictors for the development of thyroid dysfunction. During IFN- $\beta 1 \mathrm{~b}$ treatment, serum IL-6 levels rose in a consistent biphasic pattern; there was, however, no difference between patients with or without incident thyroid abnormalities.

Conclusions: We conclude that IFN- $\beta 1 \mathrm{~b}$ therapy can induce multiple alterations in thyroid function, some of which are unrelated to thyroid autoimmunity. IL-6 measurement is not useful to identify patients prone to develop thyroid abnormalities. Though thyroid dysfunction is generally subclinical and often transient, systematic thyroid assessment should be performed during IFN- $\beta 1 \mathrm{~b}$ treatment.
\end{abstract}

European Journal of Endocrinology $141325-331$

\section{Introduction}

Multiple sclerosis (MS) is a demyelinating disease of the central nervous system that is associated with an aberrant immune response to myelin and, possibly, nonmyelin self-antigens (1). Moreover, previous studies have shown a significant association between MS and several autoimmune disorders, including autoimmune thyroiditis $(2,3)$.

Recently, interferon- $\beta$ (IFN- $\beta$ ) has been widely used to treat patients with relapsing-remitting MS (4). Since type I interferons modulate the immunoregulatory system, these cytokines may precipitate autoimmune disorders. In fact, thyroid disease, with clinical manifestations of hyper- or hypothyroidism, has been reported in $5-12 \%$ of patients treated with IFN- $\alpha$ for various diseases (5-7), especially in those with preexisting autoimmunity (8-11). Apart from two case reports $(12,13)$, only one clinical study has investigated autoimmunity and thyroid function during IFN- $\beta$ treatment (14). In that study, however, a thorough evaluation of pretreatment thyroid autoimmunity and ultrasound features was not carried out.

The aim of the present study was to evaluate the effect on thyroid function and autoimmunity of a 1 -year treatment with IFN- $\beta 1 \mathrm{~b}$ in patients with relapsing-remitting MS. The presence of pre-existing thyroid autoimmunity, or other possible risk factors for developing thyroid disease, was also evaluated.

\section{Patients and methods}

\section{Patients}

Thirty-one patients, 21 women and 10 men (mean age 34.4 years, range 23-49) attending the outpatient clinic of the Department of Neurosciences, were enrolled in this study after giving written informed consent. The study protocol was approved by the local Ethical Committee. Patients were affected by MS and classified as relapsing-remitting according to Lublin criteria (15). 
Additional inclusion criteria were as follows: (i) patients with at least two acute exacerbations in the previous 2 years but clinically stable and off corticosteroid treatment for at least 30 days prior to the study; and (ii) patients whose rating score on the Kurtzke Expanded Disability Status Scale (16) ranged from 1 to 3.5.

\section{Methods}

IFN- $\beta 1$ b was administered s.c. $\left(8 \times 10^{6}\right.$ IU every other day) for 12 months. Before interferon therapy was begun, all patients were submitted to a routine clinical work-up, and the presence of familial autoimmune history was recorded. Thyroid ultrasound examination with a $7.5 \mathrm{MHz}$ real time transducer (Toshiba, Kawasaki, Japan) was carried out by the same operator (N C) at baseline and after 1 year of IFN- $\beta 1 \mathrm{~b}$ treatment. Blood samples were collected at baseline and every 3 months up to 1 year for evaluation of free thyroid hormone (triiodothyronine $\left(\mathrm{FT}_{3}\right)$ and thyroxine $\left.\left(\mathrm{FT}_{4}\right)\right)$, thyrotropin (TSH), and serum thyroglobulin (Tg) levels. Antithyroglobulin $(\mathrm{Tg}-\mathrm{Ab})$, anti-thyroid peroxidase (TPO$\mathrm{Ab}$ ), anti-TSH receptor (TR-Ab) autoantibody, and interleukin-6 (IL-6) concentrations were also assessed basally and every 3 months. A ${ }^{99 \mathrm{~m}}$ Tc thyroid scan was performed in patients developing hyperthyroidism during IFN- $\beta 1 \mathrm{~b}$ treatment.

Serum $\mathrm{FT}_{4}, \mathrm{FT}_{3}$, Tg and TPO-Ab levels were measured by specific RIAs (Sorin Biomedica, Saluggia, Italy), Tg-Ab levels by a specific IRMA assay (ICN Pharmaceutical, Asse Relegen, Belgium) and TSH by an ultrasensitive IRMA method (Diasorin, Stillwater, MN, USA). Serum IL-6 levels were determined by ELISA (Biosource, Nirelles, Belgium), with a detection limit of $2 \mathrm{pg} / \mathrm{ml}$. Normal ranges in our laboratory are as follows: $\mathrm{FT}_{4}: \quad 7.2-19.3 \mathrm{pmol} / \mathrm{l} ; \quad \mathrm{FT}_{3}: \quad 3.7-8.6 \mathrm{pmol} / \mathrm{l} ; \mathrm{Tg}$ : $<60 \mathrm{nmol} / \mathrm{l}$; TSH: $0.3-3.6 \mathrm{mIU} / \mathrm{l}$; TPO-Ab: <10 IU/ml; Tg-Ab: <50 IU/ml; TR-Ab: <16 IU/ml; IL-6: 3-8.5 pg/ $\mathrm{ml}$.

\section{Statistical analysis}

Unless otherwise stated, data are given as the mean \pm s.E. Undetectable IL-6 levels were assigned an arbitrary value of $1 \mathrm{pg} / \mathrm{ml}$, which equals one half of the detection limit (17). Mean values and percentages were compared by Student's $t$-test, ANOVA, Mann-Whitney $\mathrm{U}$ test and $\chi^{2}$ test as appropriate. A multiple logistic regression model was used for the analysis of risk factors for the development of thyroid disease.

\section{Results}

All patients $(n=31)$ completed their 1 -year IFN- $\beta 1 b$ treatment course. Among them five were affected by Hashimoto's thyroiditis at baseline, eight developed thyroid dysfunction and/or autoimmunity of various degrees during IFN- $\beta 1 \mathrm{~b}$ treatment, while 18 did not

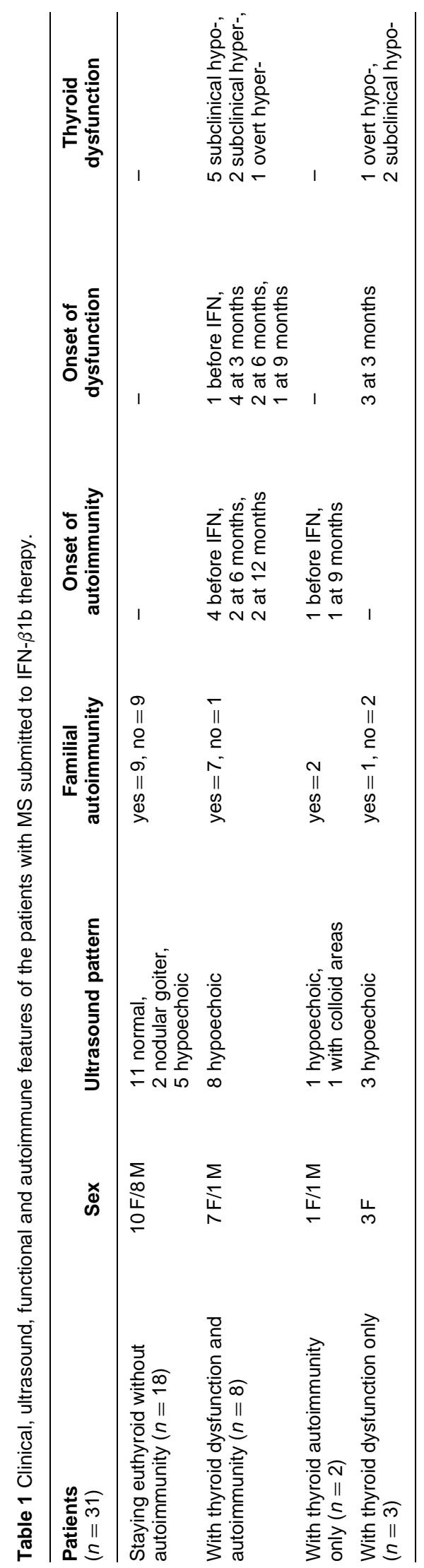


Table $2 \mathrm{FT}_{4}, \mathrm{FT}_{3}, \mathrm{TSH}, \mathrm{Tg}, \mathrm{IL}-6, \mathrm{Tg}-\mathrm{Ab}$ and TPO-Ab levels in the three patients with pretreatment Hashimoto's thyroiditis developing dysfunction during IFN- $\beta 1 \mathrm{~b}$ therapy.

\begin{tabular}{|c|c|c|c|c|c|c|c|c|c|c|c|c|c|c|c|}
\hline \multirow[b]{2}{*}{ Patient } & \multicolumn{7}{|c|}{ Basal values } & \multicolumn{7}{|c|}{ Values at onset of thyroid dysfunction } & \multirow[b]{2}{*}{ Onset/duration } \\
\hline & $\begin{array}{c}\mathrm{FT}_{4} \\
(\mathrm{pmol} / \mathrm{l})\end{array}$ & $\begin{array}{c}\mathrm{FT}_{3} \\
(\mathrm{pmol} / \mathrm{l})\end{array}$ & $\begin{array}{l}\text { TSH } \\
(\mathrm{mlU} / \mathrm{l})\end{array}$ & $\begin{array}{c}\mathrm{Tg} \\
(\mathrm{pmol} / \mathrm{l})\end{array}$ & $\begin{array}{l}\mathrm{Tg}-\mathrm{Ab} \\
(\mathrm{IU} / \mathrm{ml})\end{array}$ & $\begin{array}{l}\text { TPO-Ab } \\
\text { (IU/ml) }\end{array}$ & $\begin{array}{c}\mathrm{IL}-6 \\
(\mathrm{pg} / \mathrm{ml})\end{array}$ & $\begin{array}{c}\mathrm{FT}_{4} \\
(\mathrm{pmol} / \mathrm{l})\end{array}$ & $\begin{array}{c}\mathrm{FT}_{3} \\
(\mathrm{pmol} / \mathrm{l})\end{array}$ & $\begin{array}{l}\text { TSH } \\
(\mathrm{mlU} / \mathrm{l})\end{array}$ & $\begin{array}{c}\mathrm{Tg} \\
(\mathrm{pmol} / \mathrm{l})\end{array}$ & $\begin{array}{l}\mathrm{Tg}-\mathrm{Ab} \\
(\mathrm{IU} / \mathrm{ml})\end{array}$ & $\begin{array}{l}\text { TPO-Ab } \\
\text { (IU/ml) }\end{array}$ & $\begin{array}{c}\mathrm{IL-6} \\
(\mathrm{pg} / \mathrm{ml})\end{array}$ & \\
\hline $\begin{array}{l}\text { BoG } \\
\text { FA }\end{array}$ & $\begin{array}{r}10.8 \\
11.1 \\
7.7\end{array}$ & $\begin{array}{l}5.3 \\
5.4 \\
3.7\end{array}$ & $\begin{array}{l}2.06 \\
1.14 \\
2.61\end{array}$ & $\begin{array}{c}18.3 \\
169.8^{*} \\
1636^{*}\end{array}$ & $\begin{array}{c}4.0 \\
4.0 \\
52.0^{*}\end{array}$ & $\begin{array}{r}259.0^{*} \\
33.0^{*} \\
187.0^{*}\end{array}$ & $\begin{array}{c}1.0 \\
12.3^{*} \\
1.0\end{array}$ & $\begin{array}{r}13.9 \\
17.2 \\
8.7\end{array}$ & $\begin{array}{l}5.1 \\
6.9 \\
4.8\end{array}$ & $\begin{array}{l}4.33^{*} \\
0.08^{\star} \\
4.28^{\star}\end{array}$ & $\begin{array}{c}18.3 \\
164.5^{\star} \\
1539^{*}\end{array}$ & $\begin{array}{r}7.0 \\
21.0 \\
36.0\end{array}$ & $\begin{array}{l}419.0^{*} \\
438.0^{*}\end{array}$ & $\begin{array}{c}27.1^{*} \\
2.7 \\
5.2\end{array}$ & $\begin{array}{l}3 \text { months/transient } \\
6 \text { months/transient }\end{array}$ \\
\hline
\end{tabular}

*Pathological values.

Table $3 \mathrm{FT}_{4}, \mathrm{FT}_{3}, \mathrm{TSH}, \mathrm{Tg}, \mathrm{IL}-6, \mathrm{Tg}-\mathrm{Ab}$ and TPO-Ab levels in the eight patients developing thyroid disease during IFN- $\beta 1 \mathrm{~b}$ therapy.

\begin{tabular}{|c|c|c|c|c|c|c|c|c|c|c|c|c|c|c|c|}
\hline \multirow[b]{2}{*}{ Patient } & \multicolumn{7}{|c|}{ Basal values } & \multicolumn{7}{|c|}{ Values at onset of thyroid dysfunction/autoimmunity } & \multirow[b]{2}{*}{ Onset/duration } \\
\hline & $\begin{array}{c}\mathrm{FT}_{4} \\
(\mathrm{pmol} / \mathrm{l})\end{array}$ & $\begin{array}{c}\mathrm{FT}_{3} \\
(\mathrm{pmol} / \mathrm{l})\end{array}$ & $\begin{array}{l}\text { TSH } \\
(\mathrm{mlU} / \mathrm{l})\end{array}$ & $\begin{array}{c}\mathrm{Tg} \\
(\mathrm{pmol} / \mathrm{l})\end{array}$ & $\begin{array}{l}\mathrm{Tg}-\mathrm{Ab} \\
(\mathrm{IU} / \mathrm{ml})\end{array}$ & $\begin{array}{c}\text { TPO-Ab } \\
\text { (IU/ml) }\end{array}$ & $\begin{array}{c}\mathrm{IL}-6 \\
(\mathrm{pg} / \mathrm{ml})\end{array}$ & $\begin{array}{c}\mathrm{FT}_{4} \\
(\mathrm{pmol} / \mathrm{l})\end{array}$ & $\begin{array}{c}\mathrm{FT}_{3} \\
(\mathrm{pmol} / \mathrm{l})\end{array}$ & $\begin{array}{l}\text { TSH } \\
(\mathrm{mlU} / \mathrm{l})\end{array}$ & $\begin{array}{c}\mathrm{Tg} \\
(\mathrm{pmol} / \mathrm{l})\end{array}$ & $\begin{array}{l}\mathrm{Tg}-\mathrm{Ab} \\
(\mathrm{IU} / \mathrm{ml})\end{array}$ & $\begin{array}{c}\text { TPO-Ab } \\
\text { (IU/ml) }\end{array}$ & $\begin{array}{c}\text { IL-6 } \\
(\mathrm{pg} / \mathrm{ml})\end{array}$ & \\
\hline $\mathrm{PN}^{*}$ & 12.6 & 5.2 & 3.34 & 38.2 & 1.0 & 2.0 & $16.5^{\star \star}$ & 13.0 & $4.4^{*}$ & $4.01^{* *}$ & 33.9 & 6.0 & 5.0 & 2.7 & 3 months/permanent \\
\hline PC & 9.1 & 4.4 & 1.02 & $112.5^{\star \star}$ & 3.0 & 3.0 & 8.0 & 17.5 & 5.7 & $0.02^{* *}$ & $118.3^{\star *}$ & $64.0^{* *}$ & 4.0 & $30.5^{* *}$ & 3 months/transient \\
\hline $\mathrm{VV}^{\circ}$ & 14.8 & 5.8 & 0.58 & 50.4 & 1.0 & 8.0 & $8.6^{\star *}$ & $35.5^{\star *}$ & $13.2^{* *}$ & $0.11^{\star *}$ & $346.2^{* *}$ & 13.0 & 8.0 & $16.2^{\star *}$ & 3 months/transient \\
\hline$B G$ & 18.6 & 4.9 & 2.65 & 45.3 & 4.0 & 3.0 & 4.8 & 9.5 & 4.8 & $4.25^{\star \star}$ & 52.3 & 2.0 & 7.0 & $12.3^{\star *}$ & 3 months/transient \\
\hline TT & 8.1 & 4.6 & 1.85 & 38.1 & 1.0 & 6.0 & 7.3 & 9.3 & 4.8 & $3.74^{\star *}$ & 45.1 & 12.0 & 4.0 & 1.0 & 3 months/permanent \\
\hline $\mathrm{CR}^{\wedge}$ & 10.9 & 4.9 & 3.17 & 16.5 & 2.0 & 3.0 & $28.4^{* *}$ & 10.3 & 5.4 & 3.00 & 13.5 & 3.0 & $15.0^{* *}$ & $25.5^{* *}$ & 9 months/permanent \\
\hline TA & 10.3 & 5.2 & 2.43 & 16.3 & 14.0 & 2.0 & $20.4^{* *}$ & 11.4 & 5.8 & $3.88^{* *}$ & 18.1 & 6.0 & $10.0^{* *}$ & 1.0 & 6 months/transient \\
\hline DM & 10.9 & 6.4 & 1.18 & 31.9 & 6.0 & 3.0 & $16.5^{\star *}$ & 11.7 & 4.9 & 1.61 & 20.2 & $240.0^{* *}$ & 4.0 & $23.2^{* *}$ & 9 months/permanent \\
\hline
\end{tabular}

${ }^{*}$ At 12 months the patient developed overt hypothyroidism. ${ }^{\circ}$ At 12 months the patient developed Tg-Ab antibodies (116IU/mI). ${ }^{\wedge}$ At 12 months the patient developed subclinical hypothyroidism $(\mathrm{TSH}=7.1 \mathrm{mIU} / \mathrm{l})$. ${ }^{* *}$ Pathological values. 
develop any thyroid abnormality (Table 1 ). A significant $\mathrm{TR}-\mathrm{Ab}$ titer was never observed during the study.

Among the five patients (three female and two male) with pretreatment Hashimoto's thyroiditis, four were positive for TPO-Ab and one for both $\mathrm{Tg}-\mathrm{Ab}$ and TPO-Ab. As for their thyroid function one had subclinical hypothyroidism $\left(\mathrm{FT}_{4}: 8.9 \mathrm{pmol} / \mathrm{l}, \mathrm{FT}_{3}\right.$ : $5.2 \mathrm{pmol} / \mathrm{l}$, TSH: $3.69 \mathrm{mIU} / \mathrm{l})$ not worsening during treatment, while the other four were euthyroid. During the study period, one of them remained euthyroid but became positive also for $\mathrm{Tg}-\mathrm{Ab}(64 \mathrm{IU} / \mathrm{ml}$, at 3 months), while two developed subclinical hypothyroidism at the 3-month control, and one developed transient (lasting 6 weeks) subclinical hyperthyroidism at 6 months (Tables 1 and 2). This latter patient showed a diffuse reduction in thyroid uptake at ${ }^{99 \mathrm{~m}} \mathrm{Tc}$ scintiscan (Fig. 1), and was effectively treated with propranolol only (60 mg daily) without interrupting IFN- $\beta 1 b$.

Among the remaining 26 patients, 8 (31\%) developed thyroid disease during IFN- $\beta 1 \mathrm{~b}$ treatment (Tables 1 and 3). All of them were female, and five had a positive family history of autoimmune diseases. In detail, one patient developed a positive $\mathrm{Tg}$-Ab titer and remained euthyroid, while five (two with positive TPO-Ab titer, and three without significant autoantibody levels) became hypothyroid (four subclinical and one overt). The last two patients became positive for Tg-Ab titer and developed transient hyperthyroidism (one subclinical, one overt) after 3 months of therapy. At baseline their thyroid ultrasound pattern was not homogeneous, mainly hypoechoic. At the onset of hyperthyroidism, the thyroid ultrasound echogenicity did not change in both patients, while a diffuse reduction in uptake was observed at ${ }^{99 \mathrm{~m}} \mathrm{Tc}$ scintiscan (Fig. 1). Furthermore, the patient with overt hyperthyroidism showed a significant increase in serum $\mathrm{Tg}$ levels concomitant with the onset of hyperthyroidism. Both patients were effectively treated with propranolol (60 and $80 \mathrm{mg}$ daily) without stopping IFN therapy. Hyperthyroidism was no longer evident 6 weeks later in both cases.

At baseline, mean serum IL-6 levels were $9.7 \mathrm{pg} / \mathrm{ml}$ (95\% confidence interval (CI): 6.8-12.6). During IFN$\beta 1 \mathrm{~b}$ therapy, IL-6 values showed a biphasic behavior regardless of the presence of thyroid abnormalities (Fig. 2). In particular, serum IL-6 levels rose $\sim 2$-fold at 3 months $(20.0 \mathrm{pg} / \mathrm{ml}, \mathrm{CI}: 12.7-27.3, P<0.005$ vs basal levels), returned to baseline at 6 months (10.9 pg/ml, CI: 6.3-15.5), and then rose at 9 and 12

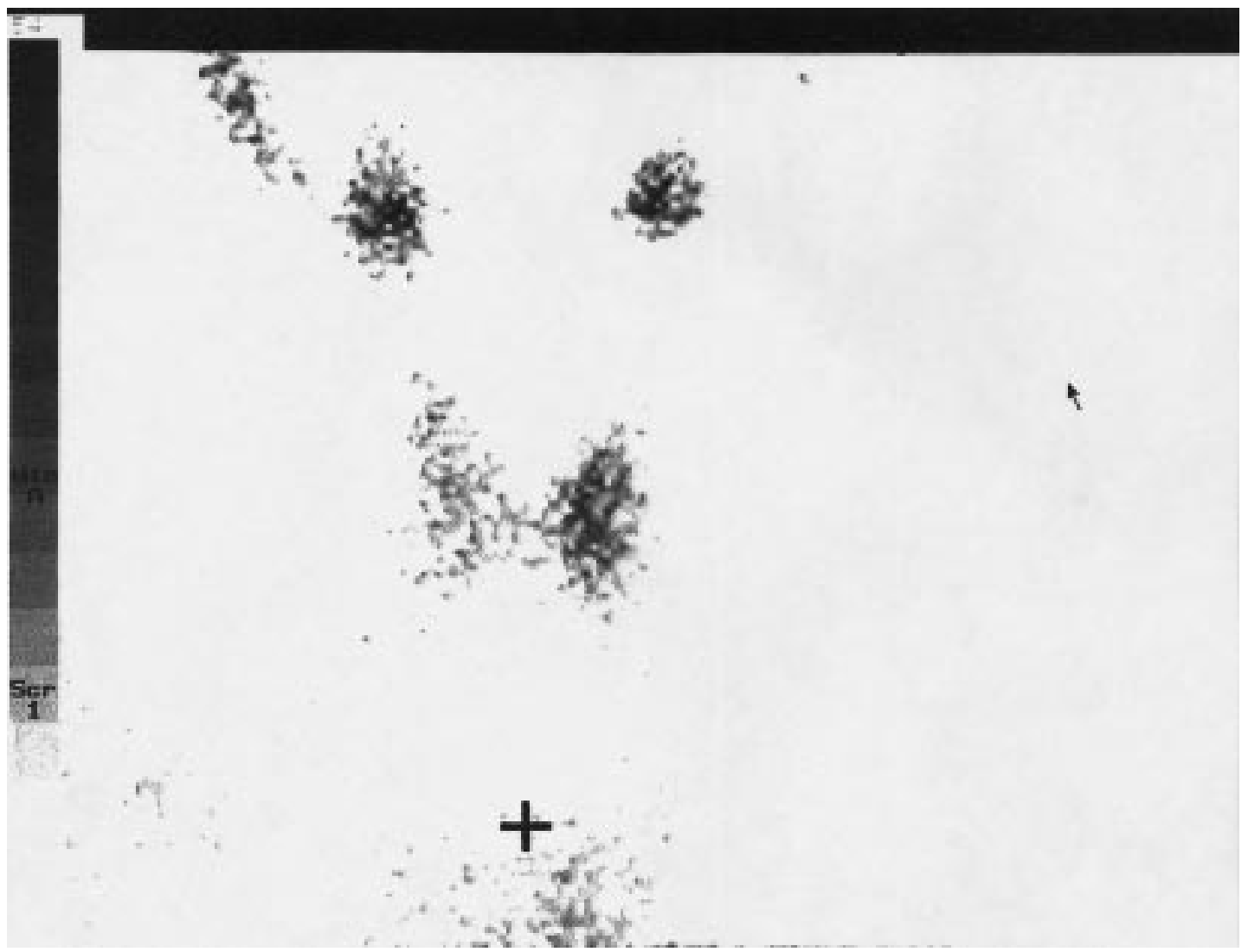

Figure 1 Reduced ${ }^{99 m} \mathrm{Tc}$ thyroid uptake in a patient with hyperthyroidism during IFN $\beta$ - $1 \mathrm{~b}$ therapy (the thyroid scintiscan of the patient with overt hyperthyroidism is shown here). 
Figure 2 Mean ( \pm S.E.M.) serum IL-6 concentrations in patients with MS at baseline and during treatment with IFN- $\beta 1 \mathrm{~b}$. Open bars $=$ patients without thyroid abnormalities; hatched bars $=$ patients with thyroid abnormalities. ${ }^{\star} P<0.05,{ }^{\circ} P<0.02$ vs baseline.

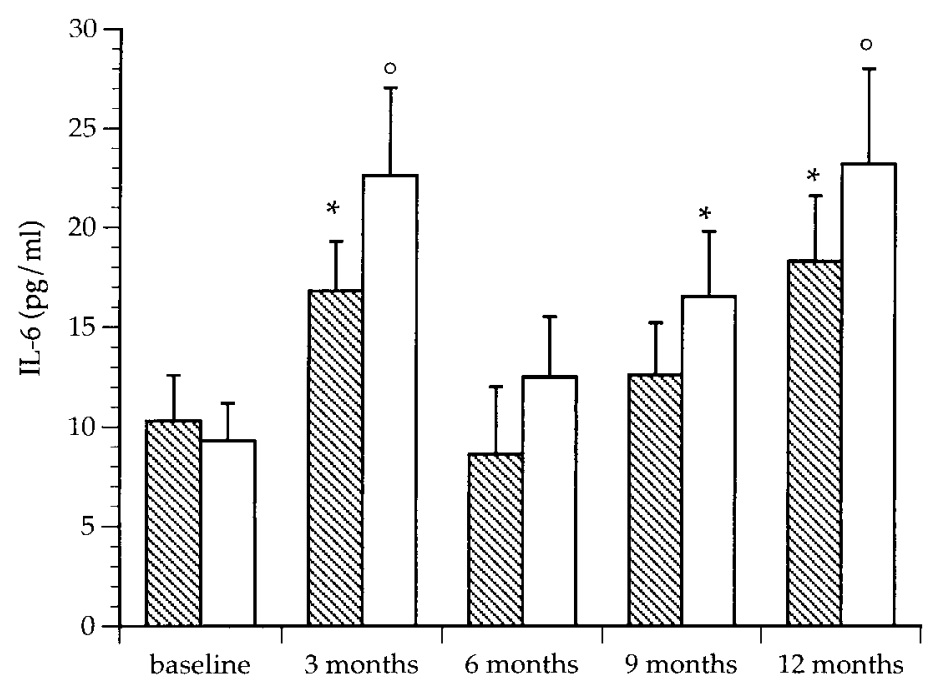

months up to $\sim 2$-fold $(14.9 \mathrm{pg} / \mathrm{ml}, \mathrm{CI}: 10.3-19.5$, and $21.7 \mathrm{pg} / \mathrm{ml}$, CI: $11.5-31.8, P=0.02$, and $P<0.01$ vs basal value respectively). No correlation between IL-6 value and thyroid hormone, TSH, Tg or thyroid autoantibody level was found.

By ultrasonography, mean thyroid volume (as estimated by the ellipsoid formula, length $\times$ width $\times$ thickness $\times 0.52$ ) was $10.6 \mathrm{ml}$ (range: $4.5-20.7$ ). At 1 year, thyroid volume was significantly increased $(13.0 \mathrm{ml}$, range 6.0-22.0, $P=0.004$ ), with no difference between patients with or without incident thyroid abnormalities. Among patients not developing thyroid dysfunction, two had a single benign solid thyroid nodule, which remained unchanged cytologically and ultrasonographically after 1 year of IFN- $\beta 1 \mathrm{~b}$ therapy. Among the eight patients who developed thyroid dysfunction and/or autoimmunity during treatment, seven showed a diffuse hypoechoic pattern without changes at the 1-year ultrasound control (Table 1).

The development of thyroid dysfunction was significantly related to positive baseline TPO-Ab titer $(P=0.01)$. By multiple logistic regression, female gender $(P=0.01$, odds ratio 55.4$)$, and the presence of a diffuse hypoechoic thyroid pattern at ultrasound examination $(P=0.04$, odds ratio 19.6) were additional risk factors. Familial autoimmunity, reported by 9/18 patients without development of thyroid disease, did not reach statistical significance $(P=0.8)$.

\section{Discussion}

Previous studies have reported an association between MS and autoimmune disorders (18), particularly thyroiditis, with a prevalence of $\sim 16 \%(2,3)$. In accord, we found $16 \%$ of patients with autoimmune thyroiditis before IFN- $\beta 1 \mathrm{~b}$ therapy, all of whom had a positive TPO-Ab titer. The development of thyroid disease, with clinical manifestations of hyper- or hypothyroidism with or without evidence of autoimmunity, has been reported in $5-12 \%$ of patients treated with IFN- $\alpha$ for various diseases (5-7). A higher incidence has been observed in patients with HCV hepatitis undergoing long-term (12 months) IFN- $\alpha$ therapy: 20\% hypothyroidism and 9\% thyrotoxicosis (19).

In the present series, the overall incidence of thyroid dysfunction during IFN- $\beta 1$ b therapy was $33 \%$, with three cases of hyperthyroidism and seven of hypothyroidism. Moreover, thyroid autoimmunity developed in $5 / 26$ patients $(19 \%)$, in one case without organ dysfunction. These data only partially agree with a recent study (14) showing, during IFN- $\beta$ treatment, thyroid autoimmunity in 5/17 (29\%) MS patients and transient hyperthyroidism in one of these five $(5.9 \%)$. In that study, however, pretreatment antithyroid antibodies were assessed only in three out of these five patients (two positive and one negative for thyroid autoimmunity), so the actual incidence of thyroid autoimmunity development was not available. Moreover, we observed an overall higher prevalence of dysthyroidism but overt thyroid dysfunction developed in only two patients $(6.1 \%)$.

Pre-existing thyroid autoimmunity has been suggested as an important risk factor during IFN- $\alpha$ therapy, thyroid disease developing in up to $60 \%$ of patients with positive baseline TPO-Ab (8-11). Similarly, in our series $75 \%$ of the patients with elevated pre-treatment TPO-Ab levels developed thyroid dysfunction during IFN- $\beta 1 \mathrm{~b}$ therapy. Furthermore, we found that risk was higher in women and was significantly enhanced by an ultrasound thyroid pattern suggestive of thyroiditis (20).

Both IFN- $\alpha$ and IFN- $\beta 1 \mathrm{~b}$ administration promote autoimmune disease, but the mechanisms of this effect are not completely understood. IFN- $\alpha$ has been suggested to induce thyroid dysfunction by stimulating the production of thyroid-inhibitory cytokines and/or 
activation of cytotoxic lymphocytes in the thyroid (21, $22)$. IFN- $\alpha$ is also known to suppress the expression of MHC class II antigens in thyroid cells (23). Thus, it seems likely that the expression of these antigens in thyrocytes is not necessary to induce thyroid autoimmunity in patients treated with IFN- $\alpha$. Recently, Yamazaki et al. (24) demonstrated that in vitro IFN- $\alpha$ and IFN- $\beta$ inhibited radioiodine $\left({ }^{125} \mathrm{I}\right)$ organification in human thyroid cells. Overall, these findings suggest a direct action of IFNs on thyroid function, possibly accompanied by autoimmunity and cytotoxicity.

Though the most likely explanation for the thyroid dysfunction occurring with IFN- $\beta 1 \mathrm{~b}$ therapy remains an autoimmune reaction, a direct inhibitory effect of IFN- $\beta 1 \mathrm{~b}$ on iodine organification may be presumed in those patients who developed hypothyroidism without thyroid autoimmunity. A similar mechanism may be involved in the thyroid volume increment observed in our study. Direct cytotoxicity may account, at least in part, for the development of transient hyperthyroidism, as suggested for IFN- $\alpha$ (10). This could explain the low ${ }^{99} \mathrm{~m}$ Tc uptake and the absence of positive TR-Ab titer observed in our patients (although a significant increase of $\mathrm{Tg}$ was detected in the patient with overt hyperthyroidism only).

To test whether thyroid tissue damage may be involved in the development of transient thyroid dysfunction, we measured both IL- 6 and Tg levels during IFN- $\beta 1 \mathrm{~b}$ treatment. In fact, similar to Tg, IL-6 has been regarded as a marker of thyroid destruction (17). In our patients, chronic IFN- $\beta 1 \mathrm{~b}$ treatment induced a significant increase of IL-6 secretion, which, however, was not associated with a concurrent increase in $\mathrm{Tg}$ levels. Although in most cases the appearance of thyroid abnormalities coincided with the first peak of IL-6 (3 months into therapy), no significant differences were observed between patients with or without thyroid dysfunction. Thus, IL- 6 increments may reflect a systemic effect of IFN- $\beta 1 b$ on the immune system rather than a direct action on the thyroid gland (25). Moreover, in agreement with a previous study with IFN- $\alpha$ (26), IL-6 concentrations did not prove useful in identifying patients developing thyroid abnormalities.

In conclusion, IFN- $\beta 1$ b therapy can induce multiple alterations in thyroid function, some of which are unrelated to thyroid autoimmunity. In addition to preexisting thyroiditis, female gender and an hypoechoic thyroid pattern are reliable predictors of thyroid abnormalities. Though thyroid dysfunction is generally subclinical and often transient, systematic thyroid assessment should be performed before and during IFN- $\beta 1 \mathrm{~b}$ treatment.

\section{Acknowledgements}

We thank Drs L Manca and A Natali for their valuable comments and assistance in analyzing the study results.

\section{References}

1 Antel JP, Freedman MS, Brodsovsky S, Francis GS \& Duquette P. Activated suppressor cell function in severely disabled patients with multiple sclerosis. Annals of Neurology 198925 204-207.

2 Kiessling WR \& Pflughaupt KW. Antithyroid antibodies in multiple sclerosis. Lancet 1980141.

3 Ioppoli C, Meucci G, Mariotti S, Martino E, Lippi F, Gironelli L et al. Circulating thyroid and gastric parietal cell autoantibodies in patients with multiple sclerosis. Italian Journal of Neurological Science $19901131-36$.

4 The IFNB Multiple Sclerosis Study Group. Interferon beta-1b is effective in relapsing-remitting multiple sclerosis. I. Clinical results of a multicenter, randomized, double-blind, placebo controlled trial. Neurology $199343655-661$.

5 Ronnblom LE, Alm GV \& Oberg KE. Autoimmunity after alphainterferon therapy for malignant carcinoid tumors. Annals of Internal Medicine 1991115 178-183.

6 Fentiman IS, Thomas DS, Balkwill FR, Rubens RD \& Hayward Jl. Primary hypothyroidism associated with interferon therapy of breast cancer. Lancet 198511166.

7 Burman P, Totterman TH, Oberg K \& Karlsson FA. Thyroid autoimmunity in patients on long-term therapy with leukocytederived interferon. Journal of Clinical Endocrinology and Metabolism $1986631086-1090$.

8 Weetman AP \& McGregor AM. Autoimmune thyroid disease: further development in our understanding. Endocrine Reviews $199415788-830$.

9 Watanabe U, Hashimoto E, Hisamitsu T, Obata H \& Hayashi N. The risk factor for development of thyroid disease during interferonalpha therapy for chronic hepatitis C. American Journal of Gastroenterology 199489 399-403.

10 Roti E, Minelli R, Giuberti T, Marchelli S, Schianchi C, Gardini E et al. Multiple changes in thyroid function in patients with chronic active $\mathrm{HCV}$ hepatitis treated with recombinant interferon-alpha. American Journal of Medicine 1996101 482-487.

11 Imagawa A, Itoh N, Hanafusa T, Oda Y, Waguri M, Mijagawa J et al. Autoimmune endocrine disease induced by recombinant interferon-alpha therapy for chronic active type C hepatitis. Journal of Clinical Endocrinology and Metabolism 1996 80 922-926.

12 Tanabashi S, Kawase Y, Ukita M, Shiroko J, Kametani M, Kumada H et al. A case of chronic hepatitis complicated by subacute thyroiditis during beta interferon treatment. Nippon Shokakibyo Gakkai Zasshi 199693 496-500.

13 Schwid SR, Goodman AD \& Mattson DH. Autoimmune hyperthyroidism in patients with multiple sclerosis treated with interferon $\beta$-1b. Archives of Neurology 199754 1169-1170.

14 Martinelli V, Gironi M, Rodegher M, Martino G \& Comi G. Occurrence of thyroid autoimmunity in relapsing-remitting multiple sclerosis patients undergoing interferon- $\beta$ treatment. Italian Journal of Neurological Science 199819 65-67.

15 Lublin FD, Whitaker JN, Eidelman BH, Miller AE, Arnason BGW $\&$ Burks JS. Management of patients receiving interferon- $\beta$ - $1 \mathrm{~b}$ for multiple sclerosis: report of a consensus conference. Neurology $19964612-18$.

16 Kurtzke JF. Rating neurologic impairment in multiple sclerosis: an expanded disability status scale (EDSS). Neurology 198333 1444-1452.

17 Bartalena L, Brogioni S, Grasso L, Rago T, Vitti P, Pinchera A et al. Interleukin-6: a marker of thyroid-destructive processes? Journal of Clinical Endocrinology and Metabolism 199479 1424-1427.

18 Seyfert S, Klappas P, Meisel C, Fisher T \& Junghan U. Multiple sclerosis and other immunological diseases. Acta Neurologica Scandinavica $19908137-42$.

19 Preziati D, La Rosa L, Covini G, Marcelli R, Rescalli S, Persani L et al. Autoimmunity and thyroid function in patients with chronic active hepatitis treated with recombinant interferon alpha-2a. European Journal of Endocrinology 1995132 587-593.

20 Marcocci C, Vitti P, Cetani F, Catalano F, Concetti R \& Pinchera A. Thyroid ultrasonography helps to identify patients with diffuse 
lymphocytic thyroiditis who are prone to develop hypothyroidism. Journal of Clinical Endocrinology and Metabolism 199172 209213.

21 Nagayama Y, Izumi M, Ashizawa K, Kiriyama T, Yokoyama N, Morita S et al. Inhibitory effect of interferon- $\gamma$ on the response of human thyrocytes to thyrotropin (TSH) stimulation: relationship between the response to TSH and the expression of DR antigens. Journal of Clinical Endocrinology and Metabolism 1987 64949-953.

22 Volpé R. Immunology of human thyroid disease. In Autoimmune Disease of the Endocrine System, pp 173-239. Ed. R Volpé. Florida: CRC Press, 1990.

23 Guerin V, Todd I, Hammond LJ \& Bottazzo GF. Suppression of HLA class II expression on thyrocytes by interferon-alpha 1 . Clinical and Experimental Immunology 199079 341-345.

24 Yamazaki K, Kanaji Y, Shizume K, Yamakawa Y, Demura H, Kanaji Yet al. Reversible inhibition by interferons alpha and beta of
${ }^{125}$ I incorporation and thyroid hormone release by human thyroid follicles in vitro. Journal of Clinical Endocrinology and Metabolism 199377 1439-1441.

25 Brod SA, Marshall GD, Henninger EM, Sriram S, Khan M \& Wolinshy JS. Interferon- $\beta 1 \mathrm{~b}$ treatment decreases tumor necrosis factor- $\alpha$ and increases interleukin- 6 production in multiple sclerosis. Neurology 199646 1633-1638.

26 Minelli R, Girasole G, Pedrazzoni M, Giuliani N, Schianchi C, Gruberti T et al. Lack of increased serum interleukin- 6 and soluble IL-6 receptor concentrations in patients with thyroid diseases following recombinant human interferon alpha therapy. Journal of Investigative Medicine 199644 370-374.

Received 17 February 1999

Accepted 14 June 1999 